\title{
Mild Camurati-Engelamann disease presenting with exophthalmos as the first and only manifestation: A case report
}

\author{
RUIZHI JIAJUE, BO WU, YAN JIANG, OU WANG, MEI LI, XIAOPING XING and WEIBO XIA \\ Department of Endocrinology, Key Laboratory of Endocrinology, Ministry of Health, \\ Peking Union Medical College Hospital, Chinese Academy of Medical Sciences, Beijing 100730, P.R. China
}

Received June 12,2015; Accepted April 7, 2016

DOI: $10.3892 / \mathrm{mmr} .2016 .5548$

\begin{abstract}
Camurati-Engelmann disease (CED; MIM 131300), or progressive diaphyseal dysplasia, is a rare autosomal dominant bone disease, which is caused by mutations in the transforming growth factor- $\beta 1$ (TGF $\beta 1)$ gene on chromosome 19q13.1-13.3. Extremely variable penetrance has been reported to be associated with $\mathrm{CED}$, the most common features of which are limb pain, waddling gait and muscle weakness. The present study reported on a consanguineous Chinese family with one affected individual that initially presented with exophthalmos, which has not previously been reported as an initial manifestation of CED. The proband was a 22-year-old woman that presented with progressive proptosis. Except for increased serum levels of alkaline phosphatase and C-terminal telopeptide of type I collagen, no other biochemical abnormalities were detected. Whole-body radiological and bone scintigraphic investigations revealed that hyperostosis and sclerosis predominantly affected the cranial bones, including the skull base, and only mildly affected the long bones. A heterozygous mutation involving a $G$ to A transition at the cDNA position +653 of $T G F \beta 1$ was detected in the patient only, but not in her family members, by automated DNA sequencing using an ABI DNA sequencer (Model 377). Based on the clinical, biochemical, radiological and genetic findings, a diagnosis of CED was confirmed. Considering the phenotypic variability associated with CED and the unique manifestations of the patient described in the present study, CED should be taken into account regarding the differential diagnosis of exophthalmos.
\end{abstract}

Correspondence to: Professor Weibo Xia, Department of Endocrinology, Key Laboratory of Endocrinology, Ministry of Health, Peking Union Medical College Hospital, Chinese Academy of Medical Sciences, 1 Shuaifuyuan, Wangfujing, Dongcheng, Beijing 100730, P.R. China

E-mail: xiaweibo@medmail.com.cn

Key words: Camurati-Engelmann disease, transforming growth factor- $\beta 1$, phenotypic variability, exophthalmos

\section{Introduction}

Camurati-Engelmann disease (CED; MIM 131300), or progressive diaphyseal dysplasia, is a rare autosomal dominant bone disease, which is associated with molecular defects within the transforming growth factor- $\beta 1$ (TGF $\beta 1$ ) gene on chromosome 19q13.1-13.3 (1-3). The hallmark of CED is bilateral and symmetrical cortical thickening of the diaphyses of the long bones, both on the periosteal and endosteal surface, resulting in sclerotic and expanded diaphyseal segments, and narrowed medullary cavities. Hyperostosis is usually initiated at the diaphyses of the femora and tibiae, and gradually spreads to involve all bones, including the skull base, which has been reported to occur in $>50 \%$ of all patients (4-6).

CED has variable penetrance and wide expressivity $(4,7)$. The majority of patients exhibit initial manifestations, which most commonly include limb pain, waddling gait and muscle weakness, before the age of 30 , and occasionally before the age of $10(4,7)$. Other associated features include reduced subcutaneous fat, delayed puberty and hepatosplenomegaly $(4,6)$. Sclerosis of the skull base is most associated with hearing and/or vision loss, headaches and exophthalmos (6). Although biochemical measurements are usually normal in CED, elevated erythrocyte sedimentation rate (ESR) and abnormal bone turnover markers have been reported $(4,8,9)$. At present, in the English literature, $>300$ cases of CED have been reported $(4,6)$; however, to the best of our knowledge, no case has been reported to present with exophthalmos as the initial manifestation.

The present study reported on a consanguineous Chinese family with one affected individual, as confirmed by genetic analysis, which presented with progressive proptosis as the initial manifestation. The clinical, biochemical and radiological findings of the proband are reported.

\section{Subjects and methods}

Subjects. The present study examined the unaffected parents and the affected female proband in a single Chinese family. The 22-year-old female proband presented her first manifestation at the age of 19 years and was first admitted to our clinic in August 2013. Medical history was recorded and comprehensive physical examinations were performed, including degree of exophthalmos and intraocular pressure measured by 
Table I. Primer sequences used for polymerase chain reaction of transforming growth factor- $\beta 1$.

\begin{tabular}{|c|c|c|c|}
\hline Exon & Direction & Primer sequence & Fragment length (bp) \\
\hline 1 & $\begin{array}{l}\text { Sense } \\
\text { Antisense }\end{array}$ & $\begin{array}{l}\text { 5' ATCCCCTATTCAAGACCACCCAC } 3^{\prime} \\
5^{\prime} \text { TCCСCCTATTGCTTGTCTCCCTCT } 3^{\prime}\end{array}$ & 906 \\
\hline 2 & $\begin{array}{l}\text { Sense } \\
\text { Antisense }\end{array}$ & $\begin{array}{l}\text { 5' CTGTCAGCTCCAAAACTCC 3' } \\
\text { 5' ACCTTGTAACCAGCCGAC 3' }\end{array}$ & 345 \\
\hline 3 & $\begin{array}{l}\text { Sense } \\
\text { Antisense }\end{array}$ & $\begin{array}{l}\text { 5' TGGGTACTGTTGGGGAGGAT 3' } \\
\text { 5' GGGAGAAACAGGGGTGGG 3' }\end{array}$ & 337 \\
\hline 4 & $\begin{array}{l}\text { Sense } \\
\text { Antisense }\end{array}$ & $\begin{array}{l}\text { 5' TGGGGTTTGCTCCTTCCTTC 3' } \\
\text { 5' TGTGGGAGTCAGGGGATAGG 3' }\end{array}$ & 292 \\
\hline 5 & $\begin{array}{l}\text { Sense } \\
\text { Antisense }\end{array}$ & $\begin{array}{l}\text { 5' CGCCCCACTTATCTATCCCTC } 3^{\prime} \\
5^{\prime} \text { TCTTACACCCAGACCTCATCCC } 3^{\prime}\end{array}$ & 379 \\
\hline 6 & $\begin{array}{l}\text { Sense } \\
\text { Antisense }\end{array}$ & $\begin{array}{l}\text { 5' GTTATTTTGTATGTTCCAGG 3' } \\
\text { 5' CTCTGTGGGTCTTCATAGC 3' }\end{array}$ & 704 \\
\hline 7 & $\begin{array}{l}\text { Sense } \\
\text { Antisense }\end{array}$ & $\begin{array}{l}\text { 5' TAGAAGATAAGAGAGACCG 3' } \\
\text { 5' TGCTATGGTGACTGAATG 3' }\end{array}$ & 691 \\
\hline
\end{tabular}

bp, base pairs.

Non-Contact Tonometer, weight and height, full examination of the skin, chest, abdomen and genital organs. Skeletal deformities were also examined. The present study was approved by the institutional review board (ethics committee) of the Department of Scientific Research, Peking Union Medical College Hospital (PUMCH; Beijing, China). Prior to study participation, written informed consent was obtained from all subjects for DNA analysis, other investigations and permission of image publication.

Biochemical investigations. All biochemical investigations were performed at the Central Laboratory, PUMCH. Overnight fasting blood samples were obtained and full-day urine collection was conducted. Complete blood count, hormone levels, thyroid function, serum levels of phosphate $(\mathrm{P})$, total calcium $(\mathrm{Ca}), \mathrm{ESR}$, high sensitivity $\mathrm{C}$ reactive protein and alkaline phosphatase (ALP) were measured by standard methods. Hormonal testing and detection of the serum levels of 25-hydroxyvitamin $\mathrm{D}, 1,25$ dihydroxyvitamin $\mathrm{D}$, intact parathyroid hormone and C-terminal telopeptide of type I collagen $(\beta-\mathrm{CTX})$ were measured using an automated Roche electrochemiluminescence system (E170; Roche Diagnostics, Basel, Switzerland). Urinary levels of $\mathrm{Ca}$ and $\mathrm{P}$ were analyzed using a Urinary Chemical Analyzer (Clinitek 500; Siemens Healthcare, Malvern, PA, USA).

Radiological assessment. Radiography of the extremities and skull, computed tomography (CT) of the head and orbital bones, and magnetic resonance imaging (MRI) of head and bone scintigraphy were performed on the proband. Radiological abnormalities were assessed by experienced radiologists at $\mathrm{PUMCH}$.

Genetic analysis. Blood samples were obtained from the patient and her parents. Genomic DNA was extracted from $0.2 \mathrm{ml}$ whole blood using a commercial DNA extraction kit (QIAamp DNA Micro kit; Qiagen, Hilden, Germany) according to the manufacturer's protocol. Using polymerase chain reaction, the seven exons and flanking intron sequences of $T G F \beta 1$ were amplified using seven pairs of primers (Table I), which were designed using Primer Premier 6.0 software (PREMIER Biosoft, Palo Alto, CA, USA) and synthesized by TsingKe Biological Technology, Beijing, China. The total volume of the reaction was $30 \mu \mathrm{l}$, including $15 \mu \mathrm{T} \mathrm{Taq}$ DNA polymerase (Takara Bio, Inc., Otsu, Japan), 2.6 $\mu$ l DNA templates, $1.2 \mu 1$ forward primer, $1.2 \mu \mathrm{l}$ reverse primer and $10 \mu \mathrm{l}$ double distilled water. Taq DNA polymerase and its standard buffer were used in all reactions under the following conditions: Initial denaturation at $94^{\circ} \mathrm{C}$ for $5 \mathrm{~min}$, followed by 30 cycles at $94^{\circ} \mathrm{C}$ for $30 \mathrm{sec}, 54-64^{\circ} \mathrm{C}$ for $30 \mathrm{sec}$ and $72^{\circ} \mathrm{C}$ for $50 \mathrm{sec}$. Direct DNA sequence analysis was performed by automated DNA sequencing using an ABI DNA sequencer (Model 377; Applied Biosystems; Thermo Fisher Scientific, Inc., Waltham, MA, USA).

Other investigations. Bone mineral density (BMD) of the proband was measured by Dual-energy X-ray absorptiometry (Lunar DPX; Lunar Corporation, Madison, WI, USA) at the posteroanterior spine (L1-4), lateral spine (L2-4), total hip, femoral neck and trochanter. Prodigy enCORE version 6.70 software (GE Healthcare, Madison, WI, USA) was used to analyze the data using the standard-array mode. Ultrasonic investigations of the thyroid, abdominal and urogenital system were also performed.

\section{Results}

The proband was a 22-year-old Chinese woman who had been complaining of bilateral and progressive proptosis (Fig. 1A) for the past 1 year. The patient experienced mild eye pain, 

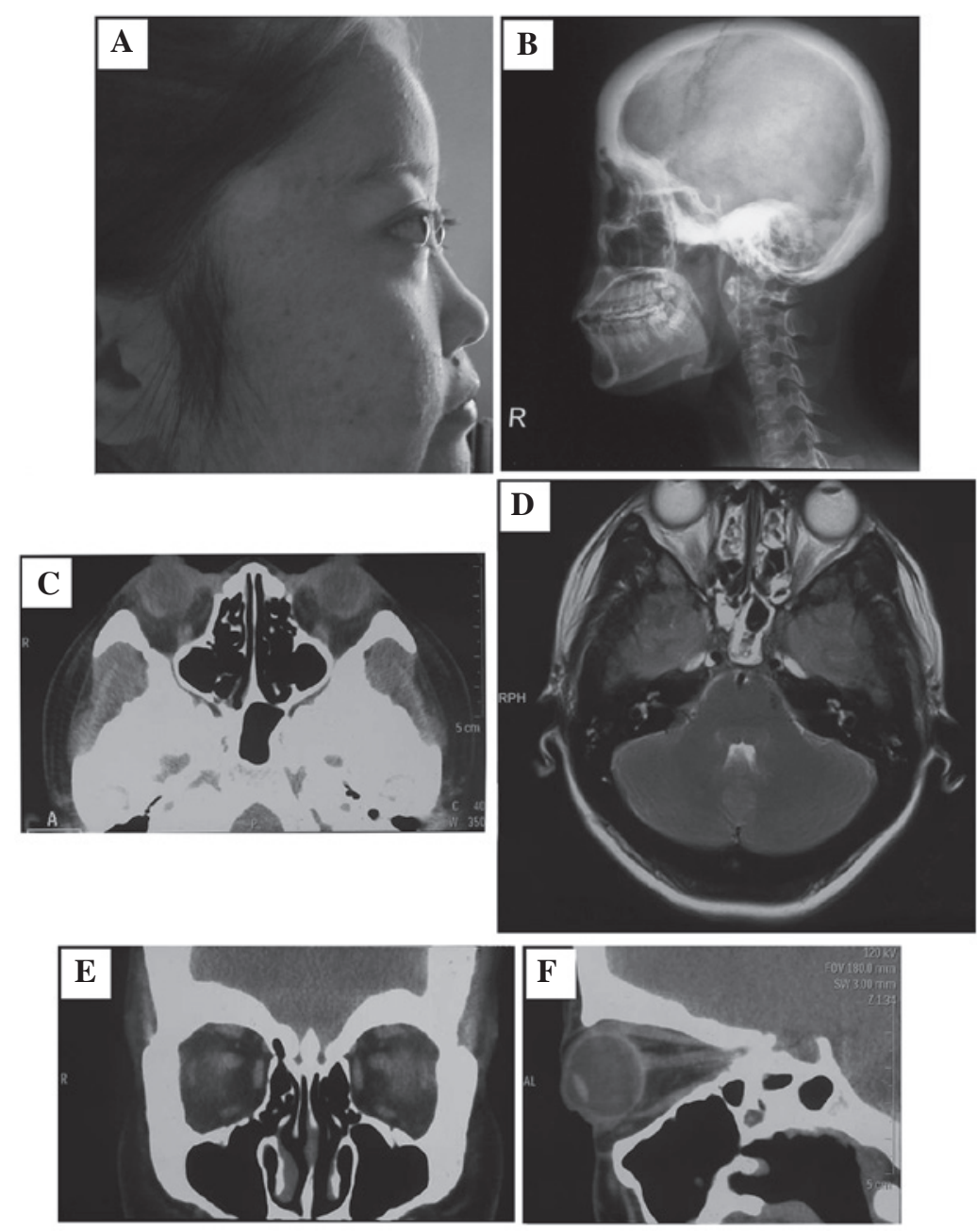

Figure 1. Physical and radiological features. A 22-year-old woman presented with (A) exophthalmos, orbital pain and high intraocular pressure; (B) sclerosis of the cranium and (B and C) skull base, as detected by (B) lateral skull radiography and (C) computed tomography (CT). (D) No compression of the optic nerves or narrowed auditory canals were detected by magnetic resonance imaging of the skull. (E) Coronal and (F) sagittal CT of the orbital bones revealed markedly thickened and sclerotic orbits, which were associated with decreased orbital volume.
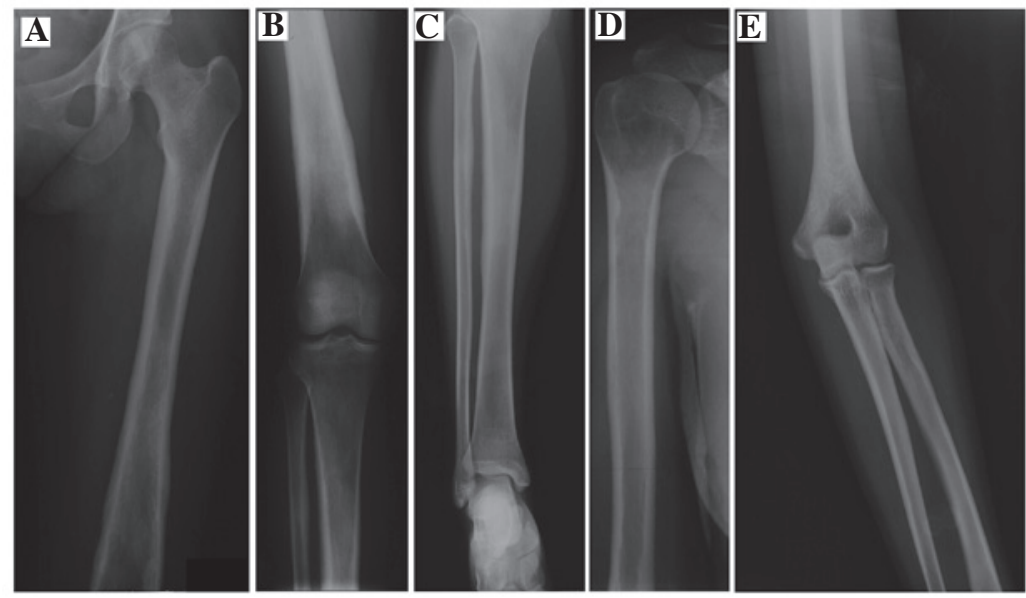

Figure 2. X-ray features of long bones. Cortical sclerosis and thickness occurred most apparently along the (A and B) femora, and relatively mildly at $(\mathrm{B}$ and $\mathrm{C})$ the upper end of tibiae and (D and E) the humeri. Narrowed medullary cavities were also detected.

discomfort accompanied by eye movement, and easy fatigability. Nonspecific bone pain occasionally occurred at the knees following certain activities or during cold weather, but was mostly unnoticeable. The patient had never exhibited a waddling gait, muscle tenderness or headaches, and had good mobility, hearing, vision and appetite. Menstruation began at the age of 13, 


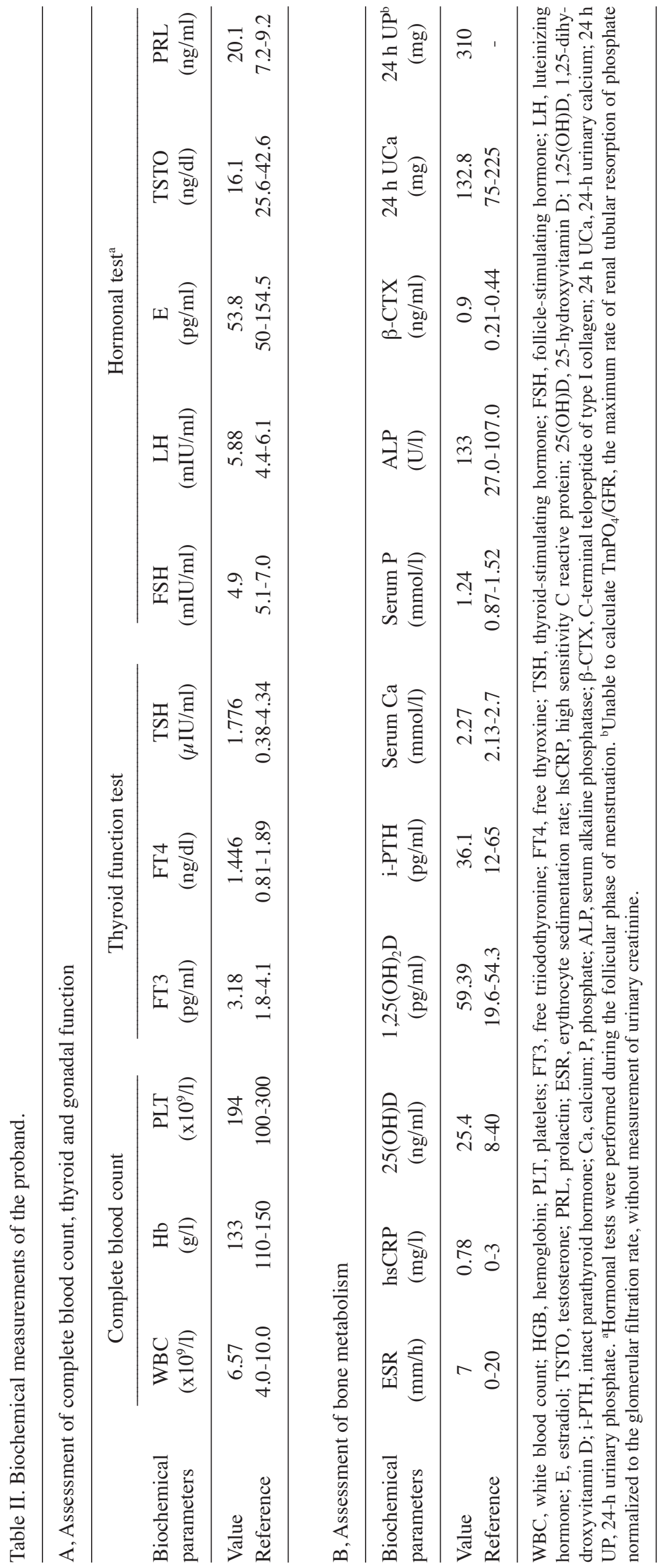




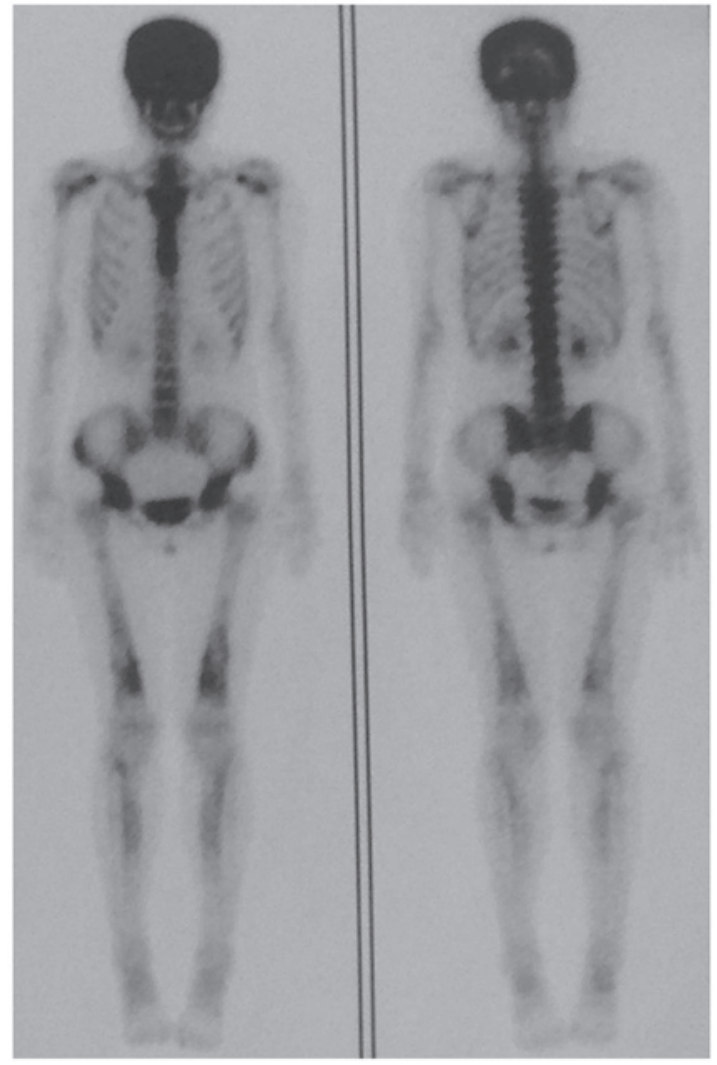

Figure 3. Bone scintigraphic manifestations. Increased tracer uptake was observed most prominently in the skull and moderately in the bilateral lower half of the femora, upper end of tibiae and shoulder joints. The rest of the skeleton was relatively unaffected.

and the patient experienced regular periods. She had previously been well with no relevant medical history. Family history was unremarkable, neither parents nor any consanguinity exhibited the features of CED. Physical examinations revealed the degree of exophthalmos (left, $20 \mathrm{~mm}$; right, $19 \mathrm{~mm}$ ); high intraocular pressure (measured by non-contact tonometer; left, $25.3 \mathrm{mmHg}$; right, $23.5 \mathrm{mmHg}$ ); normal body mass index (BMI; weight, $52 \mathrm{~kg}$; height, $1.58 \mathrm{~m}$; BMI $\left.20.8 \mathrm{~kg} / \mathrm{m}^{2}\right)$; scattered acne on the face and back; remarkable vellus hair on the back, forehead and back of neck; an enlarged mandible; Tanner stage 5 with regards to breast development and pubic hair; no hepatosplenomegaly; no muscle weakness in the extremities; and no evident skeletal deformities, such as cubitus valgus, genu valgum, scoliosis and elongation of the long bones.

No specific biochemical abnormalities were detected in the patient (Table II), except for increased levels of the bone formation marker ALP and the bone resorption marker $\beta$-CTX.

Skull radiography and CT detected prominent hyperostosis and sclerosis of the calvarium (Fig. 1B) and skull base (Fig. 1B and C). Coronal (Fig. 1E) and sagittal (Fig. 1F) CT of the orbital bones revealed markedly thickened and sclerotic orbits, associated with decreased orbital volume shown in the sagittal view, which may 'push out' the eyeballs and may have caused the obvious exophthalmos presented by the patient. No obvious abnormalities, including compression of the optic nerves or narrowed auditory canals, were detected by MRI (Fig. 1D) of the head. X-rays of the long bones (Fig. 2) detected cortical sclerosis, and thickness occurred in descending severity in both femora, the upper end of both tibiae and both humeri. Narrowed medullary cavities were also detected. Bone scintigraphy (Fig. 3) revealed markedly increased tracer uptake in the skull and moderately increased uptake in the bilateral lower half of the femora, upper end of tibiae and shoulder joints. The rest of the skeleton was relatively unaffected.

A heterozygous mutation involving a $\mathrm{G}$ to $\mathrm{A}$ transition at the cDNA position +653 of TGF 1 (Fig. 4) was detected only in the patient, but not in her parents, thus resulting in an arginine to histidine substitution at amino acid 218 (R218H) near the carboxy-terminus of the latency associated peptide (LAP). Such mutation was not detected in any of her parents, including a de novo mutation in the proband.

BMD values at L1-4, L2-4, total hip, femoral neck and trochanter were $1.245(\mathrm{Z}=1.3), 1.246(\mathrm{Z}=1.1), 1.063(\mathrm{Z}=0.9)$, $0.988(Z=0.7)$ and $0.817(Z=0.8)$, respectively. All BMD values of the proband were markedly increased, especially in the spine, compared with the site-, age- and gender-matched mean reference values (10). Ultrasonic investigations of the thyroid, abdominal and urogenital systems detected no obvious abnormalities.

\section{Discussion}

The TGF $\beta 1$ gene, on chromosome 19q13.1-13.3, has been well identified as the causative gene of CED (1-3). The full-length precursor form of TGF $\beta 1$ consists of the signal peptide, the LAP and the mature peptide. Post-translational processing by proteolytic cleavage and dimerization leads to release of the signal peptide and dimerization of the LAP, due to the formation of a disulphide bridge (11). Dimerization of the LAP maintains TGF $\beta 1$ in a latent form, either alone as a small latent complex, or in conjunction with a latent TGF $\beta 1$-binding protein as a large latent complex, which can not be activated to bind the TGF $\beta 1$ receptor unless subjected to specific activation conditions (11-14). TGF $\beta 1$ gene mutations, all of which have been reported to increase TGF $\beta 1$ protein activity (11), are associated with these activation conditions. At present, 13 mutations have been reported in the literature $(2,4,11,15,16)$. Over $80 \%$ of all mutations reported thus far are missense mutations clustered in exon 4 , and around the residues responsible for homodimerzation of LAP (Cys223 and Cys225) (4). An arginine residue at position 218 is the most common mutation (4), which was detected in the proband in the present study. Mutations in exon 4 destabilize the disulphide bridge, disrupt the LAP-TGF $\beta 1$ association, and result in subsequent release of the mature activated $\operatorname{TGF} \beta 1(4,17)$.

Almost all manifestations of CED can be explained by enhanced TGF $\beta 1$ activity. Although TGF $\beta 1$ stimulates bone formation and suppresses bone resorption under physiological conditions (18), it appears to stimulate entire bone turnover once mutated. Previous in vivo studies $(16,19)$, as with the patient in the present study, have detected increased levels of bone formation and bone resorption markers. In vitro, Saito et al (17) reported that CED fibroblasts with mutant (R218H) TGF $\beta 1$ promoted the proliferation of co-cultured osteoblast cells. McGowan et al (20) demonstrated that CED peripheral blood mononuclear cells with mutant (R218C) TGF 1 markedly increased osteoclast formation and bone resorption. Increased bone formation 

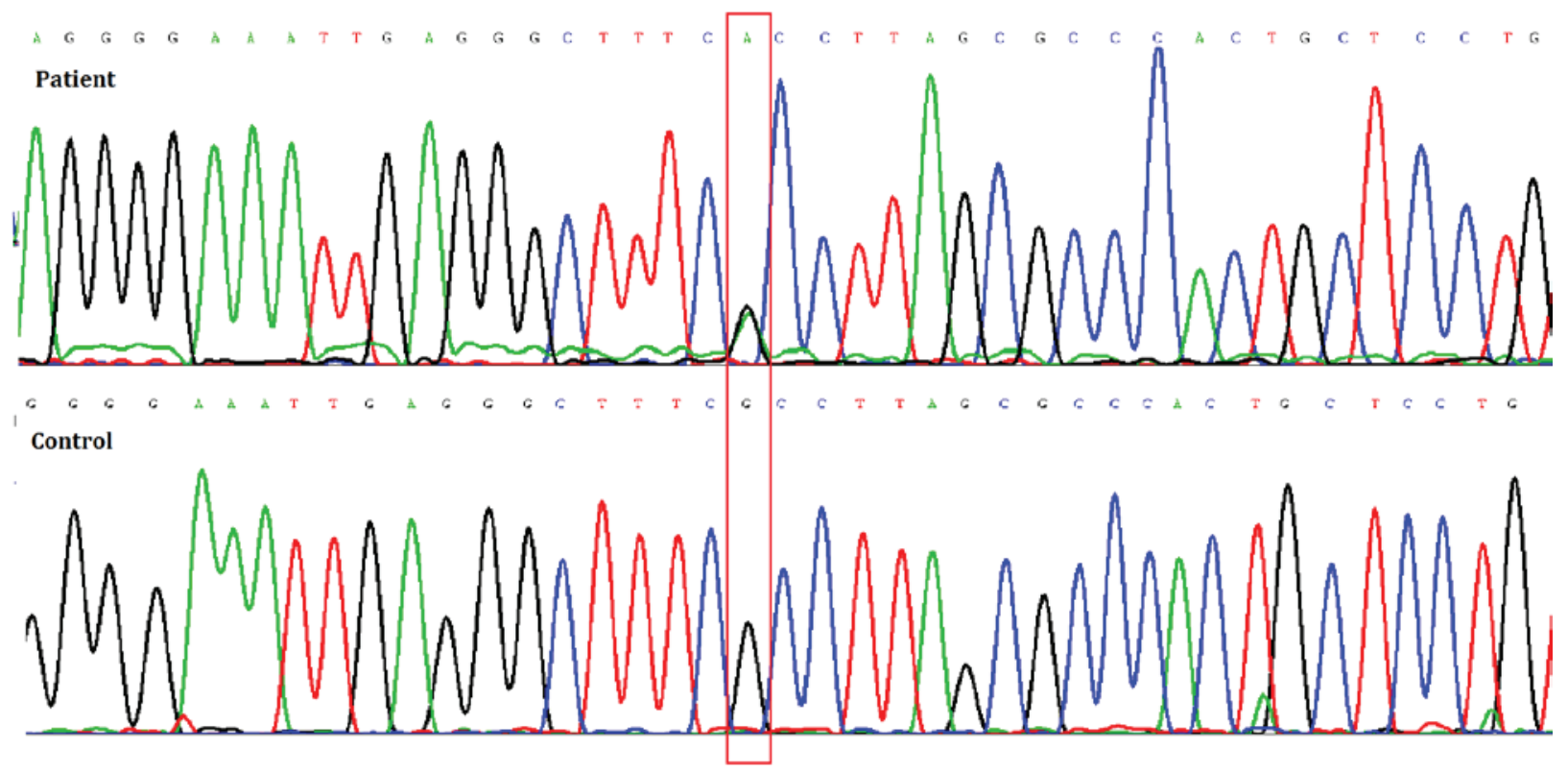

Figure 4. Sequencing of exon 4 of transforming growth factor- $\beta 1$ in the proband and in a person without metabolic bone disease. G to A transition at the cDNA position +653 was detected, resulting in an arginine to histidine substitution at amino acid 218 (R218H). The control was a healthy female individual in our laboratory, who also give us permission to use her blood to do this genetic test.

leads to typical hyperostosis in CED. The majority of clinical features are secondary to hyperostosis and sclerosis of the skeleton, including bone pain due to periosteal stretching; skeletal deformities (such as genu valgum and enlarged mandible) due to inappropriately increased bone growth; hearing and/or vision loss, headaches and exophthalmos due to sclerosis of the skull base; and systemic manifestations (such as anemia, leucopenia and hepatosplenomegaly) due to hyperostosis encroaching on marrow cavities, with secondary extramedullary haemopoiesis in the spleen and liver (8,21-23). TGF $\beta 1$ also has a crucial role in the inhibition of myogenesis (24) and adipogenesis (25), which may explain the reduced subcutaneous fat and easy fatigability associated with CED.

However, TGF $\beta 1$ mutation alone is insufficient to explain the extremely variable penetrance and wide-range expressivity associated with CED, both between families sharing the same mutation, and even within families with genetic anticipation in successive generations $(4,5,26)$. The present study provides strong evidence of variable penetrance for CED. The majority of typical patients with CED, including several cases with the same R218H mutation (4,7,27-30), initially present with limb pain and a waddling gait. The patient described in the present study is the first case, to the best of our knowledge, to initially present with only exophthalmos. Alongside occasional fatigability, nonspecific limb pain, and mild or moderate hyperostosis of long bones, the present patient appeared to suffer from mild CED. Furthermore, some unaffected patients have been reported within the investigated cases of the R218 mutation (4,7,28-30), further indicating the extreme phenotypic variability in CED.

Single nucleotide polymorphisms (SNPs) in $T G F \beta 1$ were once considered the cause of variability in CED; however, no association between promoter SNPs or coding SNPs and disease severity have been reported (7,30). Whyte et al (16) detected a receptor activator of nuclear factor $\kappa$-B ligand (RANKL) variant and an allele dosage effect in a family of two patients with different disease severity, thus suggesting that RANKL may be a potential gene, other than $T G F \beta 1$, which has the ability of modulating the outcome of the principal TGF 1 1 mutation, resulting in CED variability. Janssens et al (4) proposed another theory, that the latent TGF 31 -binding protein may control the degree of TGF $\beta 1$ activation and thus the variable penetrance of CED. In addition, it was suggested that the capacity of a mutation to alter the conformation structure needed for premature activation of the mature peptide depended on the presence of the latent TGF $\beta 1$-binding protein. Different from the majority of other tissues, which produce large latent complexes (LAP-TGF $\beta 1$-latent TGF $\beta 1$-binding protein), bone predominantly produces small latent complexes (LAP-TGF $\beta 1$ ), which is readily available and easily activated by $T G F \beta 1$ mutations. As a result, patients with CED predominantly exhibit bones abnormalities, whereas the majority of other tissues are unaffected. Further studies are required to confirm or reject this theory.

In conclusion, the present study was the first, to the best of our knowledge, to describe a patient with exophthalmos as the initial manifestation of mild CED with the heterozygous missense mutation $\mathrm{R} 218 \mathrm{C}$ in the $T G F \beta 1$ gene. CED is a sclerosing bone disease with extreme variability, the potential modulatory factors of which require further investigation. Regarding the results of the present study, it may be recommended that CED should be considered in the differential diagnosis of exophthalmos, easy fatigability and nonspecific limb pain in young individuals. Clinical examination, biochemical evaluation, bone scintigraphic and radiological investigations, and genetic analysis are all helpful in confirming diagnosis.

\section{Acknowledgements}

The authors of the present study would like to thank the patients and their families for participating in this study. 
The present study was supported by grants from the Ministry of Science and Technology of the People's Republic of China (National Science and Technology Major Projects for 'Major New Drugs Innovation and Development'; grant no. 2008ZX09312-016), the National Natural Science Foundation of China (grant nos. 81471088 and 81170805), the Beijing Natural Science Foundation (grant no. 7121012) and the National Key Program of Clinical Science (grant no. WBYZ2011-873).

\section{References}

1. Janssens K, Gershoni-Baruch R, Van Hul E, Brik R, Guañabens N, Migone N, Verbruggen LA, Ralston SH, Bonduelle M, Van Maldergem L, et al: Localisation of the gene causing diaphyseal dysplasia Camurati-Engelmann to chromosome 19q13. J Med Genet 37: 245-249, 2000.

2. Janssens K, Gershoni-Baruch R, Guañabens N, Migone N, Ralston S, Bonduelle M, Lissens W, Van Maldergem L, Vanhoenacker F, Verbruggen L and Van Hul W: Mutations in the gene encoding the latency-associated peptide of TGF-beta 1 cause Camurati-Engelmann disease. Nat Genet 26: 273-275, 2000

3. Kinoshita A, Saito T, Tomita H, Makita Y, Yoshida K, Ghadami M, Yamada K, Kondo S, Ikegawa S, Nishimura G, et al: Domain-specific mutations in TGFB1 result in Camurati-Engelmann disease. Nat Genet 26: 19-20, 2000.

4. Janssens K, Vanhoenacker F, Bonduelle M, Verbruggen L, Van Maldergem L, Ralston S, Guañabens N, Migone N, Wientroub S, Divizia MT, et al: Camurati-Engelmann disease: Review of the clinical, radiological, and molecular data of 24 families and implications for diagnosis and treatment. J Med Genet 43: 1-11, 2006.

5. Sparkes RS and Graham CB: Camurati-Engelmann disease. Genetics and clinical manifestations with a review of the literature. J Med Genet 9: 73-85, 1972.

6. Carlson ML, Beatty CW, Neff BA, Link MJ and Driscoll CL: Skull base manifestations of Camurati-Engelmann disease. Arch Otolaryngol Head Neck Surg 136: 566-575, 2010.

7. Campos-Xavier B, Saraiva JM, Savarirayan R, Verloes A, Feingold J, Faivre L, Munnich A, Le Merrer M and Cormier-Daire V: Phenotypic variability at the TGF-betal locus in Camurati-Engelmann disease. Hum Genet 109: 653-658, 2001

8. Smith R, Walton RJ, Corner BD and Gordon IR: Clinical and biochemical studies in Engelmann's disease (progressive diaphyseal dysplasia). Q J Med 46: 273-294, 1977.

9. Hernández MV, Peris P, Guañabens N, Alvarez L, Monegal A Pons F, Ponce A and Muñoz-Gómez J: Biochemical markers of bone turnover in Camurati-Engelmann disease: A report on four cases in one family. Calcif Tissue Int 61: 48-51, 1997.

10. Wu XP, Yang YH, Zhang H, Yuan LQ, Luo XH, Cao XZ and Liao EY: Gender differences in bone density at different skeletal sites of acquisition with age in Chinese children and adolescents. J Bone Miner Metab 23: 253-260, 2005.

11. Janssens K, ten Dijke P, Ralston SH, Bergmann C and Van Hul W: Transforming growth factor-beta 1 mutations in Camurati-Engelmann disease lead to increased signaling by altering either activation or secretion of the mutant protein. J Biol Chem 278: 7718-7724, 2003.

12. Oklü R and Hesketh R: The latent transforming growth factor beta binding protein (LTBP) family. Biochem J 352 Pt 3: 601-610, 2000.

13. Pedrozo HA, Schwartz Z, Mokeyev T, Ornoy A, Xin-Sheng W, Bonewald LF, Dean DD and Boyan BD: Vitamin D3 metabolites regulate LTBP1 and latent TGF-beta1 expression and latent TGF-beta1 incorporation in the extracellular matrix of chondrocytes. J Cell Biochem 72: 151-165, 1999.
14. Bonewald LF, Wakefield L, Oreffo RO, Escobedo A, Twardzik DR and Mundy GR: Latent forms of transforming growth factor-beta (TGF beta) derived from bone cultures: Identification of a naturally occurring $100-\mathrm{kDa}$ complex with similarity to recombinant latent TGF beta. Mol Endocrinol 5: 741-751, 1991

15. Wu S, Liang S, Yan Y, Wang Y, Li F, Deng Y, Huang W, Yuan W, Luo N, Zhu C, et al: A novel mutation of TGF betal in a Chinese family with Camurati-Engelmann disease. Bone 40: 1630-1634, 2007.

16. Whyte MP, Totty WG, Novack DV, Zhang X, Wenkert D and Mumm S: Camurati-Engelmann disease: Unique variant featuring a novel mutation in TGF $\beta 1$ encoding transforming growth factor beta 1 and a missense change in TNFSF11 encoding RANK ligand. J Bone Miner Res 26: 920-933, 2011.

17. Saito T, Kinoshita A, Yoshiura Ki, Makita Y, Wakui K, Honke K, Niikawa N and Taniguchi N: Domain-specific mutations of a transforming growth factor (TGF)-beta 1 latency-associated peptide cause Camurati-Engelmann disease because of the formation of a constitutively active form of TGF-beta 1. J Biol Chem 276: 11469-11472, 2001.

18. Janssens K, ten Dijke P, Janssens S and Van Hul W: Transforming growth factor-beta1 to the bone. Endocr Rev 26: 743-774, 2005.

19. Wang C, Zhang BH, Liu YJ, Hu YQ, He JW and Zhang ZL: Transforming growth factor- $\beta 1$ gene mutations and phenotypes in pediatric patients with Camurati-Engelmann disease. Mol Med Rep 7: 1695-1699, 2013.

20. McGowan NW, MacPherson H, Janssens K, Van Hul W, Frith JC, Fraser WD, Ralston SH and Helfrich MH: A mutation affecting the latency-associated peptide of TGFbetal in Camurati-Engelmann disease enhances osteoclast formation in vitro. J Clin Endocrinol Metab 88: 3321-3326, 2003.

21. Crisp AJ and Brenton DP: Engelmann's disease of bone - a systemic disorder? Ann Rheum Dis 41: 183-188, 1982.

22. Gupta S and Cheikh IE: Camurati-Engelmann disease in conjunction with hypogonadism. Endocr Pract 11: 399-407, 2005.

23. Meczekalski B, Czyzyk A, Podfigurna-Stopa A, Rydzewski B, Sroczynski J, Lipinska M, Sokalski J, Krawczynski M, Jamsheer A, Katulski K and Genazzani A: Hypothalamic amenorrhea in a Camurati-Engelmann disease - a case report. Gynecol Endocrinol 29: 511-514, 2013.

24. Massagué J, Cheifetz S, Endo T and Nadal-Ginard B: Type beta transforming growth factor is an inhibitor of myogenic differentiation. Proc Natl Acad Sci USA 83: 8206-8210, 1986.

25. Ignotz RA and Massagué J: Type beta transforming growth factor controls the adipogenic differentiation of $3 \mathrm{~T} 3$ fibroblasts. Proc Natl Acad Sci USA 82: 8530-8534, 1985.

26. Saraiva JM: Progressive diaphyseal dysplasia: A three-generation family with markedly variable expressivity. Am J Med Genet 71: 348-352, 1997.

27. Liang YH, Li W, Li LY, Ye YY and Lu GX: A mutation in TGF betal gene encoding the latency-associated peptide in a Chinese patient with Camurati-Engelmann disease. Zhonghua Yi Xue Yi Chuan Xue Za Zhi 23: 502-504, 2006

28. Park SJ, Yoon CS, Park HW, Choi JR, Chung JS and Lee KA: The first Korean case of Camurati-Engelmann disease (progressive diaphyseal dysplasia) confirmed by TGFB1 gene mutation analysis. J Korean Med Sci 24: 737-740, 2009.

29. Bhadada SK, Sridhar S, Steenackers E, Dhiman V, Mortier G, Bhansali A and Van Hul W: Camurati-Engelmann disease (progressive diaphyseal dysplasia): Reports of an Indian kindred. Calcif Tissue Int 94: 240-247, 2014.

30. Wallace SE, Lachman RS, Mekikian PB, Bui KK and Wilcox WR: Marked phenotypic variability in progressive diaphyseal dysplasia (Camurati-Engelmann disease): Report of a four-generation pedigree, identification of a mutation in TGFB1, and review. Am J Med Genet A 129A: 235-247, 2004. 